\title{
The Heidelberg Catechism: A 16th century quest for unity
}

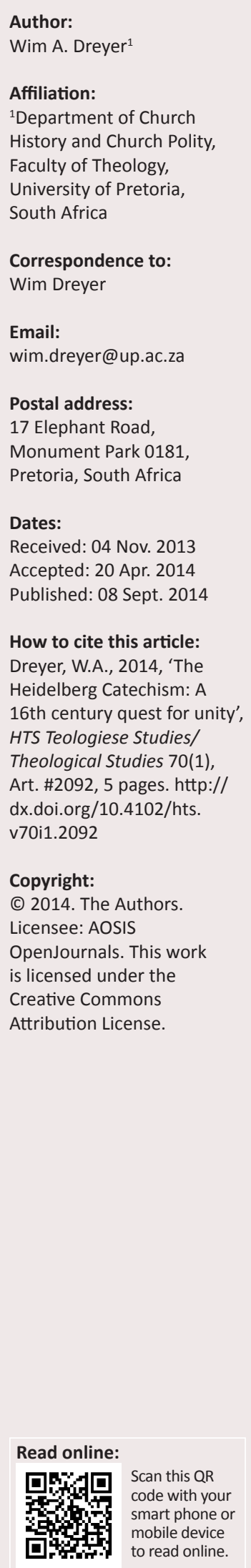

In this contribution the view is presented that the Heidelberg Catechism should be regarded as an attempt to promote unity between 16th century reformers and churches in the Palatinate. This, to some extent, determined the content of the Catechism resulting in some controversial issues receiving less attention. This in turn not only made the Catechism acceptable to a wide spectrum of Reformed Christianity, but also resulted in a creative and unique contribution to Reformed theology, almost a 'third option'. It was soon used in different Reformed territories as a confession and acclaimed for its clarity in formulating the basic Reformed faith. Today the Heidelberg Catechism is regarded as one of the most 'ecumenical' documents of the 16th century. As such, it still promotes unity amongst many Reformed churches, including those in South Africa.

\section{Introduction}

'The Heidelberg Catechism speaks with a certain freshness, youthfulness and relevance to us' (Haitjema 1962:11). This explains the many publications on the Catechism, especially during previous centennials (for an overview see Klooster 1966:3-78). Leading theologians of the 20th century are of the opinion that 'the Catechism is the most important confession in the history of Europe down to the present day' (Klooster 1966:74). The high esteem in which the Catechism is held also reflects in the numerous publications which appeared in recent years in preparation of the 450-year celebration of the Heidelberg Catechism.

At the beginning of the 21st century, many Reformed churches in Africa, Asia, Europe and the United States of America (USA) still uphold the Catechism as confession and basis of catechetical instruction. The Catechism remains an authentic expression of Reformed faith which Christians from different denominations can identify with. Some even go as far as proposing the Catechism as a basis for denominational unification (Klooster 1965:23).

The importance of the Heidelberg Catechism in South Africa cannot be underestimated. The first reports on the Heidelberg Catechism in South Africa date from 1655. 'Ziekentrooster'1 [deacon] Wijlant reports in his diary that during his visit to the Cape of Good Hope he regularly read from 'Ursinus', meaning Het Schatboek der Verklaringen van de Heidelbergse Catechismus by David Pareus and translated by Festus Hommius in 1602, as well as sermons on the Catechism, published by Lansbergius in 1616 (see Oberholzer 1986:7-8).

The use of the Catechism for catechesis and preaching were continued by the 'ziekentroosters' until the beginning of the 19th century, a period during which very few ordained ministers were active on the Cape frontier and most ecclesial duties were performed by elders, deacons and especially 'ziekentroosters'. The extensive use of the Heidelberg Catechism for more than 300 years had a fundamental influence on the spirituality of Reformed churches in South Africa.

The Heidelberg Catechism is still influential in churches such as the Dutch Reformed Church, Uniting Reformed Church, Reformed Churches in South Africa, Netherdutch Reformed Church in Africa, Maranatha Reformed Church of Christ and many others. These churches maintain the Catechism as confession as well as basis of catechetical instruction, but also as symbol of unity between the various churches. With the Belgic Confession and the Canons of Dordt it forms the Three Formularies of Unity.

\section{Early attempts to promote unity}

From a historical perspective, the lack of church unity forms an important backdrop to the Heidelberg Catechism. In this contribution, it is proposed that the Catechism should inter alia

1.Ziekentroosters' were lay people trained to minister to sailors of the merchant fleet of the United Dutch East India Company (Voic) which had a very high mortality rate. When the 'ziekentroosters' were in port, or if they settled in colonies, they continued their ministry in frontier areas where no ordained ministers were available. The Dutch word ziekentrooster' means 'consoling the sick'. Heidelberg Catechism Sunday 1 starts with the very question of our only 'troos' [consolation] in life and in death. 
be understood within the context of 16th century efforts to promote unity between the various groups, leaders and churches of the Reformation.

The relationship between Lutheran and Reformed groups were often tense, marked by sporadic and sometimes violent conflict. With the threat of Roman Catholic retaliation in mind, unity was a very serious and important matter. Unity was not only something the church confessed, but the lack of it had very real political and existential consequences.

Following the initiative of Philipp I of Hessen, the Marburg Colloquium of 1529 is one of the better known efforts to bring Luther, Melanchton, Zwingli and other Swiss leaders closer together (see Bakhuizen van den Brink 1967:52-53). Luther and Zwingli met in Marburg to discuss the right understanding of the Lord's Supper, but could not reach agreement. However, the 15 Marburg Articles were signed by both.

John à Lasco (1499-1560) was one of the most dynamic church organizers in the 16th century. He spent much of his career establishing Reformed churches and instituted evangelical practices in the German-speaking territories of the Holy Roman Empire and beyond. As superintendent, Lasco reformed the East Frisian territorial church, using inter alia, the Marburg Articles.

After the Marburg Colloquium, relations between Luther and the Swiss reformers were continually changing, for better or for worse. Leading theologians from various cities, groups and churches were in constant correspondence with each other and attempts to establish greater unity were made.

To mention one example: A rumour was spreading that a council of the Roman Catholic Church would convene in Mantua during 1537 (Bakhuizen van den Brink 1980:81, 221). Although this never happened, Martin Bucer and Wolfgang Capito were anxious to bring about more visible unity between the Lutheran and Swiss churches (Cochrane 1966:97).

The German-speaking churches of Zurich, Bern, Schaffhausen, Mühlhausen, Biel, St. Gall, Basel and Strasbourg convened on the 30th of January 1536 in the Augustinian convent in Basel to work on a confession which would be acceptable to German and Swiss churches and give expression to a unified response and apology to counter Roman Catholic criticism.

Bullinger, Myconius and Grynaeus were appointed to work on a confession, which they completed and made ready for print in only three days (Cochrane 1966:97). Bucer and Capito assisted with the article on the Lord's Supper. The first edition of the confession was published in Latin and signed by all the delegates on the 4 th of February 1536. Leo Judae translated the confession into German (Dreyer 2009). Delegates from the participating cities convened a second time on the 27th of March 1536 and unanimously ratified the First Helvetic Confession.
The quest for unity is clear from a paragraph added to the German translation of the First Helvetic Confession, formulated by Martin Bucer and Leo Judae (translated from the original in Böckel 1847:116; Cochrane 1966):

In these articles, we in no way prescribe a single rule of faith to all churches. After all, we recognize no rule of faith other than the Holy Scriptures. Who then accepts this confession, although he would use terminology other than those we used, is notwithstanding regarded as in line with us. We are primarily concerned about the matter (of faith), and the truth, and not about words. We give everyone the freedom to use the terminology that is best suited to use in his church, and we reserve the right and freedom to defend ourselves against a perversion of the true meaning of this confession. We have made use of this terminology in the present time, to convey our beliefs. (p. 98)

It is not clear whether this paragraph was ever officially part of the First Helvetic Confession, as it did not appear in the original Latin text. However, when the German translation was presented to Luther by Bucer and Capito, Luther expressed his warm approval and promised to further unity and harmony with the Swiss. In turn, Bucer and Capito also signed the Wittenberg Concord which Melanchton had composed (Cochrane 1966:98).

This mutual commitment to unity did not last long. Luther resumed his controversy with the Swiss and in his 'Short Confession of the Sacrament' (1544) his criticisms became very sharp and severe. This should be understood against the backdrop of his differences with the Schwärmer and the Roman Catholic theologians on the sacraments. The Lord's Supper remained the crucial point of difference between the various groups and churches (Barth 2009:325-331).

Despite the differences between Luther and the Swiss reformers, John Calvin regarded Martin Luther as the man who taught him the gospel. He would speak of Luther as the primo aurora exortu - the bright, rising, Morningstar of the Reformation (Dreyer 2009:1; cf. Balke 1980:1-2). There can be no doubt that Calvin had the utmost respect for Luther and his theology (Dreyer 2009:1).

How important church unity had been to someone like John Calvin, reflects in his letter to Archbishop Cranmer (1552), when he passionately exclaimed that he would 'cross ten seas for the sake of the unity of the church' (Dreyer 2009). Despite these sentiments, neither Calvin's efforts nor Martin Bucer's untiring mediation between the different groups, were able to prevent the growth of mutually exclusive traditions.

It should also be mentioned that some churches continued their efforts to establish good relations with one another. Their particular confessions were circulated between themselves, indicating a yearning for greater church unity. Several of these confessions were also published together not in opposition to each other, but complementary to one another (Jahr 1964:13). These confessions should be seen as links in a chain - each one was created and functioned independently, but yet, especially in terms of content, were interconnected and interdependent (Jahr 1964:16). 


\section{Context of the Heidelberg Catechism}

Soon after the introduction of the Reformed faith into the Palatinate, major conflict and controversy broke out. For many years, especially under Elector Otto Heinrich (1556-1559), religious intolerance and violence raged in cities like Heidelberg.

In 1559, Frederick III became Elector of the Palatinate. Against the background of ecclesial turmoil it is understandable that Frederick III kept unity high on the agenda. It was not only important to the church, but also to the social and political well-being of the Palatinate.

The battle between the Roman Catholic Church and the Protestants raged violently. At the same time, after Luther's death in 1546, major disagreement among the Lutherans broke out. In addition, the Schwärmer caused trouble and it also seemed as if the Lutherans and Calvinists were in competition to gain more power and influence. A fierce battle of words raged, with major disputes on the Lord's Supper, headed by the Lutheran professor Tielemann Heshusen and the Calvinist deacon Wilhelm Klebitz (Oberholzer 1986:1).

Frederick III adopted the Calvinistic view on the Lord's Supper, and favoured the Calvinists with all his princely power. During 1562, as part of his attempts to gain more control and establish greater ecclesial unity, he reorganised the theological college and removed Heshusen and Klebitz from their positions. In a further attempt to put an end to the religious disputes, Frederick III ordered the writing of a catechism.

In these matters, Frederick III relied on advice given to him by Melanchton, who was convinced that greater unity and reform of the church would not be possible without a proper confession. Frederick decided a catechism could serve as a confession, as well as a standard for catechesis and preaching in the Palatinate.

As part of his reorganisation, Frederick III appointed Zacharias Ursinus (born 1534 in Breslau) as rector of the theological college and author of the new catechism (Barger 1914:xviii). This was not without reason, as he was educated in both the Lutheran and Reformed traditions. Frederick needed a scholar conversant with Lutheran and Reformed theology.

Ursinus studied at the University of Wittenberg. He not only studied with Melanchton, but also lived in his house. After completing his studies with Melanchton, he travelled to France where he furthered his knowledge of Greek and Hebrew. On the journey he met Calvin, and he came under his influence (Oberholzer 1986:2; cf. Dreyer 2009). He also studied in Zurich during 1560, where he came under the influence of Bullinger. He then completed his dissertation at the University of Heidelberg, after which he started lecturing in Dogmatics.
Although Ursinus is regarded as the primary author of the Catechism, several other theologians (especially Olevianus) made submissions and were involved in the preparation of the Catechism. Other academics, like Thomas Erastus of the medical faculty, were also involved (Haitjema 1962:12). Ursinus also made use of the catechisms of Zurich, Geneva, Emden and Strasbourg as well as those written by Melanchton, Calvin, Beza and Bullinger. Thus the Heidelberg Catechism became representative of a broad spectrum of 16th century Reformed theology (Oberholzer 1986:2).

Originally, the Catechism consisted of 323 questions and answers. The first draft was not accepted, probably due to its length and the fact that it was more focused on theological issues. It also differed significantly from the Augsburg Confession in its exposition of the sacraments (Barger 1914:xxiii). The exposition of the sacraments in the first draft reflected much of Zwingli's views and needed modification, especially in light of the strong emotions and differences on the matter. If the Heidelberg Catechism were to promote unity, the articles on the sacraments needed reformulation.

Furthermore, the current Question 80 did not form part of the first draft, neither of the original German edition (Haitjema 1962:203). It was only added in later editions, probably under the influence of Olevianus and Frederick himself, to counter the anathema expressed by the Council of Trent (1545-1563) and to make it more acceptable to the Lutherans. It is also remarkable that much of what Luther had formulated in the Schmakaldian Articles (II/2) in rejecting the papal mass, was repeated in Article 80 of the Heidelberg Catechism (Barger 1914:548-549). The reformulation of the articles on the sacraments and the later addition and specific formulation of Question 80 is a clear indication that the Heidelberg Catechism was not only an apologetic over and against Trent, but was also intent on promoting unity.

Ursinus reduced the draft to 108 questions and answers. The final draft with 129 questions and answers, divided into 52 Sundays, is regarded by many as the work of Olevianus. The intention was that it should be preached, taught and discussed on a weekly basis.

The Heidelberg Catechism was presented to a synod meeting on 13 January 1563 for approval. It was accepted without amendment, although the Lutheran superintendents objected to certain articles. Despite this, Frederick III signed the Catechism and gave it for implementation in the Palatinate. He sent copies of the Catechism to various political leaders and Maximilian II, the German emperor.

\section{Reception of the Catechism}

Contrary to its purpose, the publication of the Heidelberg Catechism in 1563 caused further turmoil and conflict in the Palatinate (Barger 1914:xxv). This was the result of some who were of the opinion that the Heidelberg Catechism was too Calvinistic and they accused Frederick, as patron of the Catechism, of heresy.

Frederick turned to Bullinger for assistance. Bullinger immediately sent a confession which he started working on 
during 1561, to Frederick for use in his defence. During the plague epidemic of 1562, expecting his own death, Bullinger attached his confession to his last will and testament as a legacy to the city and church in Zurich (Cochrane 1966:221). Surviving the plague, he put the confession back in the drawer but due to the serious nature of the charges against Frederick he decided to make the confession public. Bullinger's confession immediately found wide acceptance and by 1566 many Swiss churches approved it as their confession. It became known as the Second Helvetic Confession and was translated into French, English, Dutch, Polish, Hungarian, Italian, Arabic and Turkish. When the case against Frederick was heard, Bullinger's confession formed the basis of the defence and led to his acquittal.

The Heidelberg Catechism did not bring peace and unity to the Palatinate. Different Lutheran officials had to be removed from their office, before it could be implemented. In the Upper Palatinate Frederick's attempt to unite the different groups was a complete failure. The Catechism also unleashed a whole academic discourse with Lutheran theologians on the one hand and Ursinus and Olevianus on the other side. These objections mainly dealt with the Catechism's understanding of the two natures of Christ and the Lord's Supper.

These matters and controversies were also discussed at the Diet of Augsburg (1566). Maximilian II wanted the conditions of the Religious Peace of 1555 to be made applicable only to the Augsburg Confession. However, there was considerable support at the Diet for the Heidelberg Catechism and Maximilian's sentiments were not enforced. The Heidelberg Catechism stayed as a confession for the Palatinate.

The Catechism had more influence to the west, especially in the Netherlands. Two Dutch translations of the Catechism were already published by the end of 1563. These translations soon exerted great influence in the Netherlands (Bakhuizen van den Brink 1980:270). For example, the Catechism is found in all the reprints of Dathenus' Psalms, and the Convent of Wesel (1568) passed a resolution that all elders must agree to the Belgic Confession and Heidelberg Catechism (Pont 1981:81). Subsequent synods in the Netherlands took similar decisions and the Synod of Dordt (1618-1619) confirmed the Heidelberg Catechism as confession. In the following centuries the Heidelberg Catechism was translated into more than 80 languages.

In the Palatinate the Catechism controversy continued, even into the 17th century when the Reformed Simmern dynasty was replaced with the Roman Catholic Neuburg dynasty. Both Ursinus and Olevianus were removed from their positions. Ursinus died aged 49 in Neustadt (Barger 1914:xxxvi).

\section{Concluding remarks}

From the outset, the Heidelberg Catechism was meant to promote ecclesial unity (Klooster 1965:23) by integrating diverse theological views into one document. In a review of the work of Eberhard Busch (2010) on the Catechism, Brueggemann (2010) articulates this inclusive nature of the Catechism as follows:

The Heidelberg Catechism is itself a marvel. Published in 1563 by two younger theologians in Heidelberg, it offered an ecumenical statement of Reformed faith in an effort to encourage and preserve theological unity among reformers, who were tempted to peculiar extremities in interpretation. In an almost lyrical rendering, the Catechism voiced the common ground of the Reformers without probing idiosyncratic themes. It made room for the accents of Calvin, Luther, Bucer, Bullinger, Melanchthon and Beza, the principals of the time. The editors' goal was to make peaceful coexistence possible among the major reformers. (p. 38)

Brueggemann's positive assessment of the Catechism stands diametrically opposed to R.T. Kendall (1979) who felt that a document like the Heidelberg Catechism would constitute a significant departure from Calvin's theology and open the door to what later became known as Arminianism (see Beeke 1992:39-67). Kendall even goes so far as to say that the Westminster Confession and the Heidelberg Catechism commit treason against Calvin (Kendall 1979:210). Whether one agrees with Kendall's negative interpretation of the Catechism or not, it confirms that the Catechism was a deliberate attempt to reconcile divergent theological views.

According to many scholars, the authors of the Heidelberg Catechism intentionally made use of diverse Reformed publications, such as the writings of Zwingli, Calvin, Bullinger, Beza, Melanchton, Luther and others. As far as literary dependence is concerned, we cannot say that the Heidelberg Catechism derived its structure from any specific theologian or document (Bierma 2005). Even the articles on the sacraments do not reflect a distinctive doctrinal viewpoint. Indeed, on controversial theological issues the Catechism is either muted or silent. Bierma (2005) formulates it as follows:

This elusive theological ancestry should not really surprise us. By the time the HC was being composed in the early 1560s, the triadic structure and much of the doctrinal material that filled out that structure had become part of the common property of the Protestant world, and without records of the actual sources used in the preparation of the catechism, we are not in a position to establish precise literary paternity. Even more important, however, is that the HC represented an attempt by Frederick III, who personally disliked theological labels, to forge a consensus among the Melancthonians, Calvinists and Zwinglians in his realm. Little wonder, then, that so few distinctives of these theological traditions can be detected in the structure or doctrinal content of the HC. If one still insists on using labels, the most that should be said is that the HC was a Melancthonian-Reformed gloss on the altered Augsburg Confession - but a gloss that emphasized consensus among the Protestant parties of the Palatinate. To press these labels on the $\mathrm{HC}$ any harder is to do it an injustice, for the intent of the catechism was to overcome the very divisions that such labels represented. (p. 102) 
Bierma's argument is clear: It is very difficult to point out specific parts of the Catechism which might have been influenced by any specific theologian or document. But this is exactly what was needed - a confession which could not be labelled or regarded as representative of a particular point of view. It was meant to bring greater unity, even if it required certain controversial points to receive less attention.

The question is: How could one catechism integrate so many diverse theological viewpoints? The answer is: By not giving too much prominence to any specific theologian or group and observing a certain reticence and moderation on controversial issues. The result: The Catechism is not just a 'mixed up' conglomeration of different reformed traditions, but rather a well-structured, original and creative expression of Reformed faith, reflecting the convictions of its authors as well as a broad spectrum of 16 th century Reformed theology.

It could even be argued that the Heidelberg Catechism, by neither being explicitly Lutheran nor Calvinistic, neither German nor Swiss Reformed, represents a unique (third) form of Reformed theology. This made the Heidelberg Catechism acceptable to a wide audience and as such a very ecumenical document.

The Heidelberg Catechism did not receive unconditional approval in the Palatinate and as such failed in its original purpose of uniting different groups and churches. That being said, it remains clear that the Heidelberg Catechism should be regarded as an authentic 16th century effort to promote church unity. The historical context, theological orientation of its authors, integration of diverse material, inclusivity of the formulations and reformulation of certain articles (especially those on the sacraments) bear witness to this.

This 'ecumenical' character of the Heidelberg Catechism makes it possible for many churches from diverse contexts to uphold the Heidelberg Catechism as a confession, even in the 21st century.

\section{Acknowledgements Competing interests}

The authors declare that they have no financial or personal relationship(s) that may have inappropriately influenced them in writing this article.

\section{References}

Bakhuizen van den Brink, J.N., 1967, Handboek der Kerkgeschiedenis, deel 3, Reformatie en Contra-reformatie, Bert Bakker/Daamen NV, Den Haag.

Bakhuizen van den Brink, J.N., 1980, Handboek der kerkgeschiedenis, deel 3, De Tille B.V., Leeuwarden.

Balke, W., 1980, 'Calvijn en de theologische stromingen van zijn tyd', paper presented at the University of Pretoria, Pretoria.

Barger, H.H., 1914, De Heidelbergsche Kategismus als catechetisch leerboek, Kemink \& Zoon, Utrecht.

Barth, H-M., 2009, Die Theologie Martin Luthers: Eine kritische Würdigung, Gütersloher Verlaghaus, Gütersloh.

Beeke, J.R., 1992, 'Faith and assurance in the Heidelberg Cathechism and its primary composers: A fresh look at the Kendall thesis', Calvin Theological Journal 27, 39-67.

Bierma, L.D., 2005, Introduction to the Heidelberg Catechism: Sources, history, and theology, Baker Academic, Grand Rapids.

Böckel, E.G.A., 1847, Die Bekenntnisschriften der evangelisch-reformierten Kirche, F.A. Brockhaus, Leipzig.

Brueggemann, W., 2010, 'Drawn to Freedom: Christian Faith Today in Conversation with the Heidelberg Catechism', Christian Century, September, 38-40.

Busch, E., 2010, Drawn to freedom: Christian faith today in conversation with the Heidelberg Catechism, transl. W. Rader, Wm. B. Eerdmans Publishing Company, Grand Rapids.

Cochrane, A., 1966, Reformed confessions of the sixteenth century, SCM Press, London.

Dreyer, W.A., 2009, 'The Leuenberg Agreement and church unity: A possible matrix to cross ten seas with?, HTS Teologiese Studies/Theological Studies 65(1), Art. \#195, 6 pages. $\mathrm{http}: / / \mathrm{dx}$.doi.org/10.4102/hts.v65i1.195

Haitjema, Th.L., 1962, De Heidelbergse Catechismus als klankbodem en inhoud van het actuele belijden onzer kerk, $\mathrm{H}$. Veenman \& Zonen NV, Wageningen.

Jahr, H., 1964, Studien zur Überlieferungsgeschichte der Confession de foi von 1559, Neukirchener Verlag des Erziehungsvereins, Neukirchen-Vluyn.

Kendall, R.T., 1979, Calvin and English Calvinism to 1649, Oxford University Press, New York.

Klooster, F.H., 1965, 'The Heidelberg Catechism - An ecumenical creed?' Bulletin of the Evangelical Theological Society 8(1), 23-33, viewed from http://www. biblicalstudies.org.uk/pdf/bets/vol08/8-1_klooster.pdf

Klooster, F.H., 1966, 'Recent Studies on the Heidelberg Cathechism', Calvin Theological Journal 1, April, 73-78.

Oberholzer, J.P., 1986, Die Heidelbergse Kategismus in vier teksuitgawes, met inleiding en teksvergelyking, Kital, Pretoria.

Pont, A.D., 1981, Historiese agtergronde van ons kerklike reg, deel 1, Kital, Pretoria. 